\title{
Prolonged circulatory support with the intra-aortic balloon pump after myocardial infarction
}

\author{
P B DISLER, R N SCOTT MILLAR, AND I W P OBEL \\ From the Arrhythmia Clinic, Johannesburg General Hospital, and the Department of Medicine, \\ University of the Witwatersrand, Johannesburg, South Africa
}

\begin{abstract}
Disler, P B, Scott Millar, R N, and Obel, I W P (1978). Thorax, 33, 504-507. Prolonged circulatory support with the intra-aortic balloon pump after myocardial infarction. Circulation was supported by intra-aortic balloon counterpulsation for 30 and 38 days respectively in two patients with cardiogenic shock after acute myocardial infarction. One was flown $1400 \mathrm{~km}$ to Cape Town for heart transplantation but died after being weaned from the pump while awaiting a suitable donor. The other underwent successful surgical closure of a ruptured ventricular septum on the 30th day, allowing time for the edges of the ventricular septal defect to fibrose. Neither significant damage to circulating blood elements nor infection occurred, confirming the feasibility of prolonged circulatory support.
\end{abstract}

The value of intra-aortic balloon counterpulsation (IABP) in cardiogenic shock after acute myocardial infarction is limited, as only $17-20 \%$ of patients survive discontinuance of circulatory assistance (Krakauer et al., 1971; Sanders et al., 1972; Austen et al., 1976). If potentially correctable lesions, such as ventricular septal defect (VSD), mitral regurgitation, or ventricular aneurysm are present, surgery may improve survival (Mundth et al., 1972). Friable necrotic tissue, however, renders early surgery difficult. Prolonged circulatory support with IABP may allow fibrosis to develop, facilitating surgical repair.

\section{Patients and methods}

The patients were admitted to the medical intensive care unit of the Johannesburg Hospital with recent transmural myocardial infarction and grade IV cardiogenic shock (Schiedt et al., 1970) unresponsive to medical treatment. A Swan-Ganz triple lumen balloon-tipped cardiac output catheter was used first to measure and later to monitor the right atrial, pulmonary arterial, and pulmonary arterial wedge pressures and the thermodilution right ventricular output. In the patient with the VSD the shunt ratio (Verel and Grainger, 1969) was calculated from the formula: systemic arterial $0_{2}$ saturationsystemic venous $0_{2}$ saturation

pulmonary venous $0_{2}$ saturationpulmonary arterial $\mathrm{O}_{2}$ saturation.

The pulmonary venous saturation was assumed $\underset{x}{\tilde{N}}$ from the systemic arterial saturation.

The systemic output was derived by dividing the right ventricular output by the shunt ratio. Arterial pressure was measured directly via a radial artery cannula. The Avco system was used응 for IABP. A 30-ml capacity intra-aortic balloon was inserted without a side graft into the femoralo artery in each patient. During the period of counterpulsation, haemoglobin, white cell count, platelet count, blood urea and creatinine, and $N^{N}$ stigmata of haemolysis were estimated frequently. స్ట Repeated blood cultures were made. Intravenouso heparin was given to maintain the partial thrombore plastin time between 60 and 80 seconds. Prophy- $\frac{\mathscr{C}}{\mathbb{C}}$ lactic antibiotics were also given.

\section{Case reports}

CASE 1

A 52-year-old man with previous anteroseptal infarction presented with acute inferior myocardial infarction complicated by pulmonary oedema and 
grade IV cardiogenic shock (Table 1). Despite isoprenaline $(5 \mu \mathrm{g} / \mathrm{min})$, glucagon $(2 \mathrm{mg} / \mathrm{hr})$ and large doses of frusemide he remained shocked. On the second day in hospital continuous positivepressure ventilation was started, after which IABP was instituted. A rapid improvement in the patient's condition resulted. After ten days he no longer needed the ventilator, but an attempt at weaning from IABP was followed by clinical deterioration and ventricular fibrillation. After countershock IABP was re-instituted with clinical improvement. Cardiac catheterisation having confirmed the absence of a surgically correctable lesion, he was flown by passenger jet (with continuous IABP) to Cape Town for heart transplantation. No suitable donor was found, and after two weeks IABP was discontinued. The patient died the next day after 30 days of IABP. There had been no complications at the femoral artery and no clinical infection. Blood, sputum, and urine cultures remained sterile. After an initial sharp rise, the serum lactic dehydrogenase fell but remained mildly raised. Slight reticulocytosis and hyperbilirubinaemia were present. Blood urea and creatinine rose before counterpulsation started, and diminished during the period of IABP (Table 2).

\section{CASE 2}

A 53-year-old man presented with acute anterior and inferior myocardial infarction. On the third day in hospital chest pain recurred, followed by cardiogenic shock and the development of a loud pansystolic murmur and right bundle-branch block. The diagnosis of rupture of the ventricular septum was confirmed by a rise in oxygen saturation between the right atrium and the pulmonary artery. Isoprenaline infusion $(5 \mu \mathrm{g} / \mathrm{min})$ was without benefit and IABP was started with dramatic improvement (Table 1). Weaning was attempted on the 14th day but shock recurred. The patient improved again on re-starting 1:1 IABP. About the 21st day in hospital he developed peripheral blood neutropenia (Table 3), and bone marrow aspiration showed evidence of myelo-suppression attributed to either penicillin or frusemide. These drugs were withdrawn and ethacrynic acid was substituted, with rapid recovery of the neutrophils.

Table 1 Haemodynamic data

\begin{tabular}{|c|c|c|c|c|c|c|c|c|}
\hline & $\begin{array}{l}\text { Mean } \\
\text { arterial } \\
\text { pressure }\end{array}$ & $\begin{array}{l}\text { Pulmonary } \\
\text { artery } \\
\text { pressure }\end{array}$ & $\begin{array}{l}\text { Pulmonary } \\
\text { capillary } \\
\text { wedge }\end{array}$ & $\begin{array}{l}\text { Pulmonary } \\
\text { blood flow } \\
\left(1 \mathrm{~min}^{-1}\right)\end{array}$ & $\begin{array}{l}\text { Systemic } \\
\text { blood flow } \\
\left(1 \text { min }^{-1}\right)\end{array}$ & $\begin{array}{l}\text { Shunt } \\
\text { ratio }\end{array}$ & $\begin{array}{l}\text { Cardiac index } \\
\left(1 / \min / m^{2}\right)\end{array}$ & $\begin{array}{l}\text { Left ventricular } \\
\text { stroke work index } \\
\left(\mathrm{gm} . \mathrm{m} / \mathrm{m}^{2}\right)\end{array}$ \\
\hline \multicolumn{9}{|l|}{$\begin{array}{l}\text { Case } 1 \\
\text { Before }\end{array}$} \\
\hline IABP & 48 & $50 / 35$ & 35 & 3 & 3 & - & 1.5 & $<5$ \\
\hline $\begin{array}{l}\text { On } \\
\text { IABP }\end{array}$ & 83 & $40 / 30$ & 26 & 4 & 4 & - & 2 & 23 \\
\hline \multicolumn{9}{|l|}{$\begin{array}{l}\text { Case } 2 \\
\text { Before }\end{array}$} \\
\hline IABP & 45 & $38 / 25$ & 25 & $5 \cdot 2$ & 1.73 & $3: 1$ & $\begin{array}{l}3 \text { (pulmonary) } \\
1 \text { (systemic) }\end{array}$ & - \\
\hline $\begin{array}{l}\text { On } \\
\text { IABP }\end{array}$ & 80 & $34 / 15$ & 15 & 6.6 & $2 \cdot 2$ & $3: 1$ & $\begin{array}{l}3 \cdot 8 \text { (pulmonary) } \\
1 \cdot 27 \text { (systemic) }\end{array}$ & \\
\hline
\end{tabular}

Conversion: Traditional to SI units-Pressure: $1 \mathrm{mmHg}=0.133 \mathrm{kPa}$

IABP $=$ Intra-aortic balloon counterpulsation

Table 2 Haematological and biochemical data in case 1

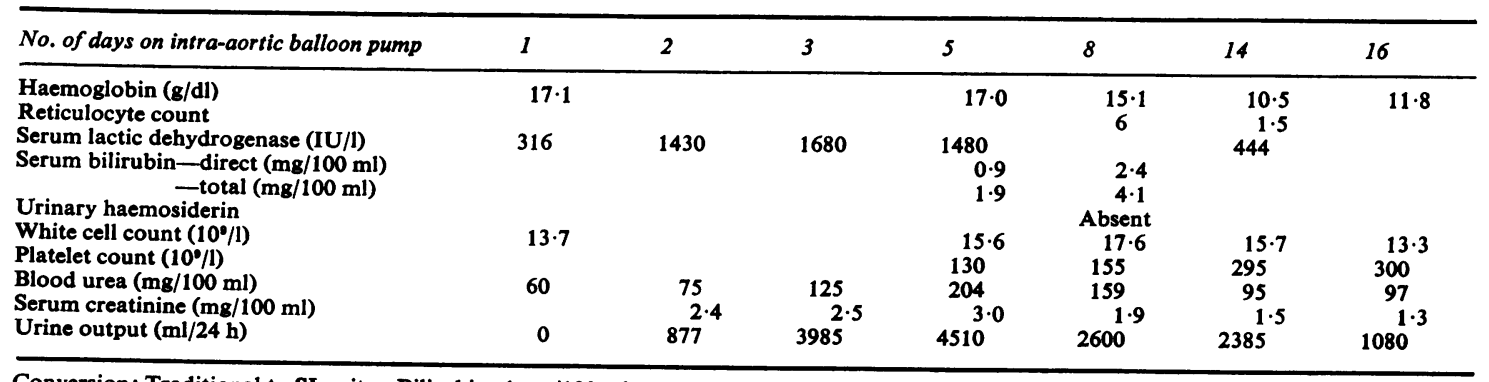


Table 3 Haematological and biochemical data in case 2

\begin{tabular}{|c|c|c|c|c|c|c|c|c|c|}
\hline $\begin{array}{l}\text { No. of days on intra-aortic } \\
\text { balloon pump; }\end{array}$ & $I$ & 3 & 8 & 12 & 18 & 22 & 24 & 26 & 29 \\
\hline $\begin{array}{l}\text { Haemoglobin (g/dl) } \\
\text { Reticulocyte count }(\%) \\
\text { Serum lactic dehydrogenase (IU/l) } \\
\text { Shumm's test } \\
\text { Serum bilirubin }(\mathrm{mg} / 100 \mathrm{ml}) \\
\text { _-direct } \\
\text { - total } \\
\text { Haptoglobin } \\
\text { Urinary haemosiderin } \\
\text { White cell count }\left(10^{\circ} / 1\right) \\
\text { Platelet count }\left(10^{\circ} / 1\right) \\
\text { Blood urea }(\mathrm{mg} / 100 \mathrm{ml}) \\
\text { Serum creatinine }(\mathrm{mg} / 100 \mathrm{ml}) \\
\text { Urine output }(\mathrm{ml} / 24 \mathrm{~h})\end{array}$ & $\begin{array}{c}20 \cdot 7 \\
215 \\
72 \\
400\end{array}$ & $\begin{array}{l}11 \cdot 6 \\
4 \cdot 0 \\
813 \\
-\mathrm{VE} \\
0 \cdot 2 \\
1 \cdot 0 \\
\text { normal } \\
\text { absent } \\
18 \cdot 4 \\
240 \\
156 \\
400\end{array}$ & $\begin{array}{r}9 \cdot 2 \\
57 \\
1710\end{array}$ & $\begin{array}{c}\text { absent } \\
10.4 \\
60 \\
2.0 \\
1075\end{array}$ & $\begin{array}{c}11 \cdot 4 \\
2 \cdot 0 \\
420 \\
-\mathrm{VE} \\
0 \cdot 2 \\
1 \cdot 1 \\
\text { normal } \\
\text { absent } \\
8 \cdot 9 \\
225 \\
55 \\
1 \cdot 8 \\
3410\end{array}$ & $\begin{array}{c}4 \cdot 2 \\
60 \\
1 \cdot 6 \\
2600\end{array}$ & $\begin{array}{c}1 \cdot 8 \\
258 \\
60 \\
1 \cdot 8 \\
2350\end{array}$ & $\begin{array}{c}4 \cdot 1 \\
54 \\
1 \cdot 3 \\
3390^{1}\end{array}$ & $\begin{array}{c}10 \cdot 1 \\
316 \\
78 \\
1 \cdot 7 \\
2330\end{array}$ \\
\hline
\end{tabular}

Conversion: Traditional to SI units-Bilirubin: $1 \mathrm{mg} / 100 \mathrm{ml} \approx 17 \cdot 1 \mu \mathrm{mol} / 1$.

Urea: $1 \mathrm{mg} / 100 \mathrm{ml} \approx 0.166 \mu \mathrm{mol} / 1$. Creatinine: $1 \mathrm{mg} / 100 \mathrm{ml} \approx 88.4 \mu \mathrm{mol} / 1$.

Left ventriculography showed a low VSD. At surgery on the 30th day (Professor T. G. O'Donovan) a $1.5 \mathrm{~cm}$ diameter VSD close to the apex was found. The edges were firm and easily held the Tefion-buttressed Prolene sutures. An aneurysm measuring $4 \times 1.5 \mathrm{~cm}$ was excised from the anterior wall of the left ventricle. After the operation artificial ventilation was needed, and IABP was continued for a further eight days. The day after removal of the balloon, a right iliofemoral arterial thrombectomy was required because pallor, cyanosis, and pain in the right leg had developed. Six days later secondary haemorrhage occurred from aseptic detachment of a patch in the femoral artery. The patch was removed and an end-to-end anastomosis performed with a good result. The patient is well and active as an engineer eight months after operation, but has evidence of a small left-to-right shunt.

\section{Discussion}

Cardiac transplantation is the only surgical procedure likely to enhance survival where cardiogenic shock is due to extensive left ventricular damage. Patients with this condition may be ideal candidates for transplantation (Barnard, 1975) in view of the absence of prolonged heart failure or raised pulmonary vascular resistance. The ability to support the circulation for several weeks by IABP allows more time to find a suitable donor. The fact that one patient was flown $1400 \mathrm{~km}$ with continuation of counterpulsation indicates that transport to transplantation centres is feasible.

The high early mortality from ventricular septal rupture after acute myocardial infarction has prompted attempts at surgical correction within the first 24 to 48 hours (Kitamura et al., 1971) Success is often limited by the necrotic margins. failing to hold sutures well. Counterpulsation max improve the clinical state, decreasing the relative left-to-right shunt by diminishing afterload (Gol\& et al., 1973). As in case 2, it may then be possible to wait three to four weeks before undertaking surgical correction, allowing fibrosis to develop io the margins of the defect, thus facilitating closure

This experience confirms the findings of Ruben $\overrightarrow{\bar{O}}$ fire and colleagues (1972) that prolonged balloom pumping does not result in significant damage to platelets or the other blood elements. The initially? very high lactic dehydrogenase levels were largely due to myocardial damage and hepatic congese tion. These levels then stabilised at twice the normal value, possibly because of mild haemolysiso Shumm's test gave negative results, and there was no haemosiderinuria. The pronounced neutropenia that developed in case 2 was clearly related to drug administration since the white cell count returnes to normal despite continued IABP. It is encourag ing that neither local nor systemic infection appeared.

An arterial thrombosis occurred in the secone patient. It is not possible to say whether it was related to the duration of pumping or to the fact that the balloon was inserted without a side grafto Circulation to the affected leg is excellent eight months after removal of the balloon.

The results confirm that counterpulsation fof more than 30 days is feasible and may be usefuto in allowing time for healing to occur around ap acquired VSD. If a patient with cardiogenic shock cannot be weaned from the IABP because of th degree of left ventricular muscle loss, transplantao tion may be considered and counterpulsation con tinued until a suitable donor is obtained. 
We thank the superintendent of the Johannesburg General Hospital for permission to publish these cases and Mrs. Elaine Lavin for secretarial help.

\section{References}

Austen, W. G., Buckley, M. J., Mundth, E. D., Daggett, W. M., Gold, H. K., and Leinbach, R. C. (1976). Counter-pulsation with an intra-aortic balloon: present-day use in the patient with left ventricular ischaemia. Transplantation Proceedings, 8, 75-78.

Barnard, C. N. (1975). The present status of heart transplantation. South African Medical Journal, 49, 213-217.

Gold, H. K., Leinbach, R., Sanders, C. A., Buckley, M. J., Mundth, E. D., and Austens, W. G. (1973). Intra-aortic balloon pumping for ventricular septal defect or mitral regurgitation complicating acute myocardial infarction. Circulation, 47, 1191-1196.

Kitamura, S., Mendez, A., and Key, J. H. (1971). Ventricular septal defect following myocardial infarction. Journal of Thoracic and Cardiovascular Surgery, 61, 186-199.

Krakauer, J. S., Rosenbaum, A., Freed, P. S., Jaron, D., and Kantrowitz, A. (1971). Clinical management ancillary to phase-shift balloon pumping in cardiogenic shock. American Journal of Cardiology, 27, 123-128.
Mundth, E. D., Buckley, M. J., Daggett, W. M., Sanders, C. A., and Austen, W. G. (1972). Surgery for complications of acute myocardial infarction. Circulation, 45, 1279-1291.

Rubenfire, M., Krakauer, J., Ciborski, M., Wajszczuk, W., Malinowski, E., Jaron, D., Freed, P., and Kantrowitz, A. (1972). Prolonged circulatory support by intra-aortic balloon pumping. Circulation. Supplement II, 45 and 46, 214.

Sanders, C. A., Buckley, M. J., Leinbach, R. C., Mundth, E. D., and Austen, W. G. (1972). Mechanical circulatory assistance: current status and experience with combining circulatory assistance, emergency coronary angiography and acute myocardial revascularisation. Circulation, 45, 1292-1313.

Schiedt, S., Ascheim, R., and Killip, T. (1970). Shock after acute myocardial infarction: a clinical and hemodynamic profile. American Journal of Cardiology, 26, 556-560.

Verel, D., and Grainger, R. G. (1969). Calculated data. In Cardiac Catheterisation and Angiocardiography, pp. 24-25. Livingstone, Edinburgh and London.

Requests for reprints to: Dr. I. W. P. Obel, Cardiac Clinic, Johannesburg General Hospital, Smit Street, Johannesburg 2001, South Africa. 